\title{
Familial mesial temporal lobe epilepsy with febrile seizures
}

INSERM

\section{Source}

INSERM. (1999). Orphanet: an online rare disease and orphan drug data base. Familial mesial temporal lobe epilepsy with febrile seizures. ORPHA:165805

\begin{abstract}
A rare, genetic, familial partial epilepsy disease characterized by simple partial seizures, complex partial seizures and/or secondarily generalized seizures, orig inating from the inner aspect of the temporal lobe, associated with an antecedant history of febrile seizures, ocurring in various members of a family. Hippocampal abnormalities (e.g. hippocampal sclerosis) may also be associated.
\end{abstract}

